\title{
КОЛИЧЕСТВЕННАЯ ОЦЕНКА ВЛИЯНИЯ РАЗЛИЧНЫХ ФАКТОРОВ НА ДОСТУПНОСТЬ ЖИЛЬЯ И ИПОТЕКИ
}

\begin{abstract}
Аннотация. В статье исследованы факторы, влияющие на объем ипотечного кредитования, оценена их значимость. Показано, как разработанная методика оценки доступности жилья для населения позволяет получить количественную оценку влияния факторов на доступность жилья (без ипотеки) и доступность кредита для населения. Позитивные изменения в прогнозировании и планировании развития жилищного фонда, действенность государственной поддержки его воспроизводства, обеспечение доступности жилья, во многом определяются наличием актуальной и достоверной информации как о жилищных условиях домашних хозяйств, так и условиях заселения квартир и индивидуальных жилых домов, то есть плотности заселения жилых единии, характеризующей интенсивность их использования. Такую информацию позволяет получить оценка условий заселения домохозяйств и жильх единии по их типам, в зависимости соответственно от размера (числа членов в домохозяйстве) и вместимости (количества жильх комнат в жилой единице). Выявлены отдельные тенденции, которые характеризуют условия заселения домохозяйств и квартир. Показаны возможности матричного аппарата при оченке условий заселения. Вносятся предложения, направленные на повышение уровня государственного управления развитием жилищного фонда и рациональным его использованием, а также на повыщение эффективности использовать бюджетные средства в жилищной сфере. Произведен расчетный эксперимент по оценке влияния стоимости жилья, уровня доходов населения и уровня ипотечной ставки на долю населения, которой жилье (ипотека) доступны.
\end{abstract}

Ключевые слова: объем ипотеки, предложение, факторы, темп роста иен, ипотечные качели, доходы населения, ипотечное кредитование, ипотечные сделки, доступность жилья, объем поглощения.

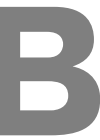
банковском и риэлторском сообществе широко обсуждаются причины такого явления, как рост объема ипотечного кредитования в условиях стагнирующей экономики, причем этот рост происходит как при снижении ставок ипотечного кредитования на 1-1,5\%, так и при росте этих ставок в том же диапазоне.

Одна из причин такого явления была исследована /1/. В этой работе было показано, что при среднесрочных колебаниях темпов роста цен повышение этих темпов приводит к снижению темпов роста объема ипотечных сделок, а снижение темпов роста цен - к повышению объема ипотеки (рис. 1). Такая закономерность получила название «ипотечные качели».

В настоящее время появилась возможность не только изучить этот вопрос в новых экономических условиях, но и дать количественную оценку влияния на объем ипотечных сделок широкого спектра факторов.
Такую возможность предоставляет новая методика оценки доступности жилья для населения /2, 3/.

В связи с этим необходимо рассмотреть структуру факторов, определяющих объем ипотечного кредитования (поглощения ипотечных кредитов) на рынке жилой недвижимости (рис. 2).

На первом уровне иерархии факторов он зависит от денежного объема предложения ипотечных кредитов, объема строительства и предложения жилья, доступности жилья и кредитов населению.

Предложение ипотечных кредитов банками в докризисные годы было одним из существенных ограничений развития ипотечного кредитования. Это было связано с недостаточным фондированием банковской системы вследствие сдерживания денежной массы в экономике финансовыми властями, и с низкой нормой сбережений домашних хозяйств в условиях растущей экономики. В период кризиса государство окончатель- 


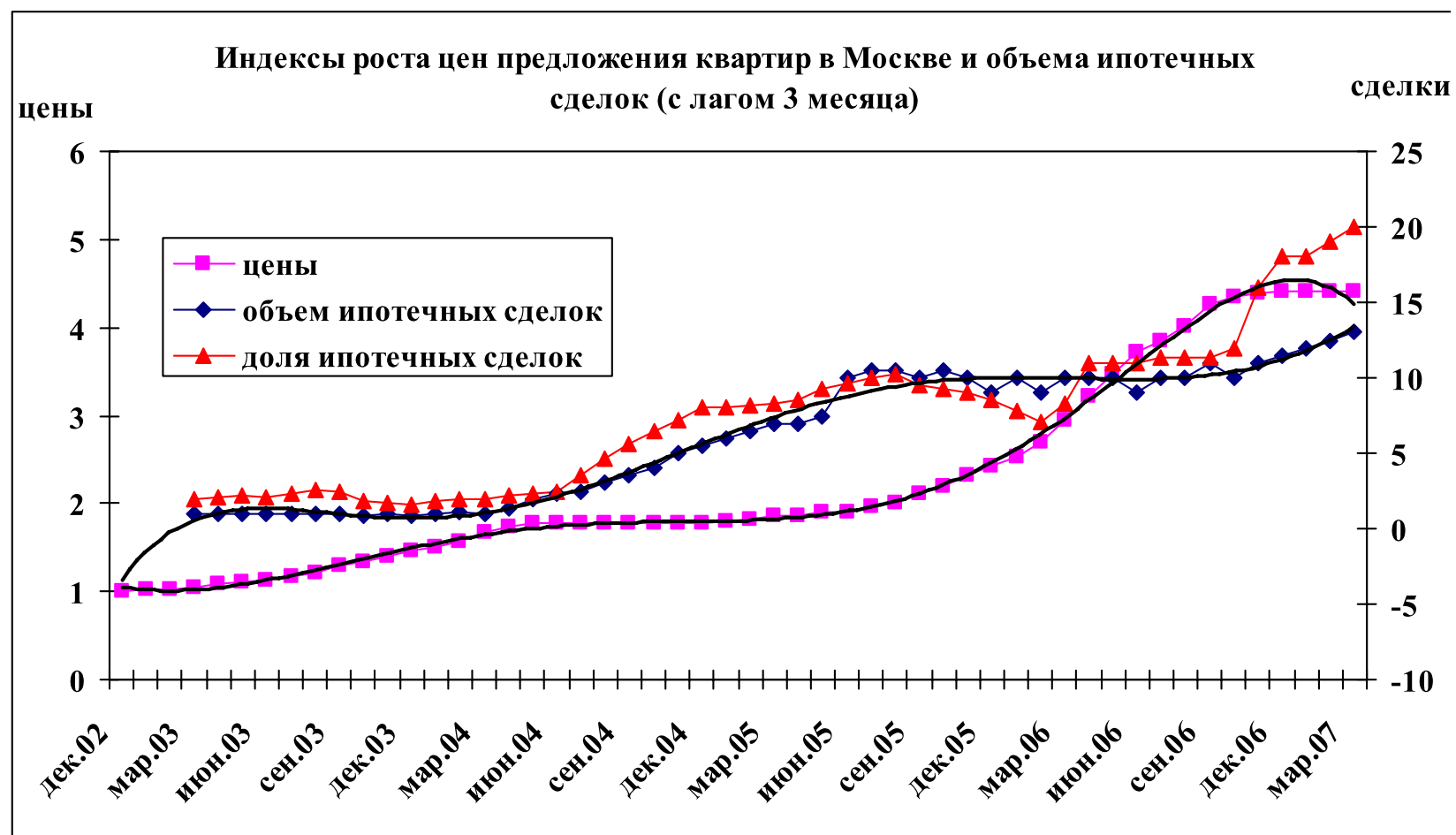

Источники: цены - OOO Sternik’s Consulting, объем ипотечных сделок - ЦБ РФ

Рис. 1. Индексы роста ичен предложения квартир и объема ипотечных сделок в Москве

но осознало роль банковской системы как кровеносной системы экономики, и решительно приняло меры к фондированию банков, вплоть до беззалогового кредитования. В результате даже в кризисном 2009 году банковские активы в России выросли на 5\% /4/ (рис. 3).

В настоящее время эта политика продолжается, например, в связи с санкционными ограничениями для госбанков во внешних заимствованиях. Не исключено и внешнее инвестирование в ипотеку - от Китая: «Китайский банк развития может предоставить российскому ВЭБ несколько миллиардов долларов на ипотечное кредитование, в рамках подписанного накануне меморандума, заявил глава корпорации Владимир Дмитриев «РИА Новости» 10.11.2014 г.».

В целом можно констатировать, что денежный объем предложения ипотеки не является в настоящий момент фактором, существенно влияющим на количество ипотечных кредитов.
Сохраняющийся исторический дефицит жилья в России приводит к тому, что в благополучный период экономического роста в 2000-е годы ограниченное предложение квартир на продажу сдерживало рост объемов ипотечного кредитования. Значительный объем построенного за последние 10 лет жилья, а главное - снижение темпов роста доходов населения и вследствие этого - спроса на жилье привели к тому, что в среднесрочном периоде (до начала нового подъема экономики) объем строительства и предложения квартир стал малозначимым фактором.

Таким образом, в сложившихся условиях объем ипотечного кредитования сдерживается в первую очередь объемом спроса на жилье и ипотеку.

В свою очередь, спрос на жилье и ипотеку определяется такими факторами второго уровня, как доступность жилья и ипотеки для населения и склонность населения к расходованию накоплений (см. рис. 2). 


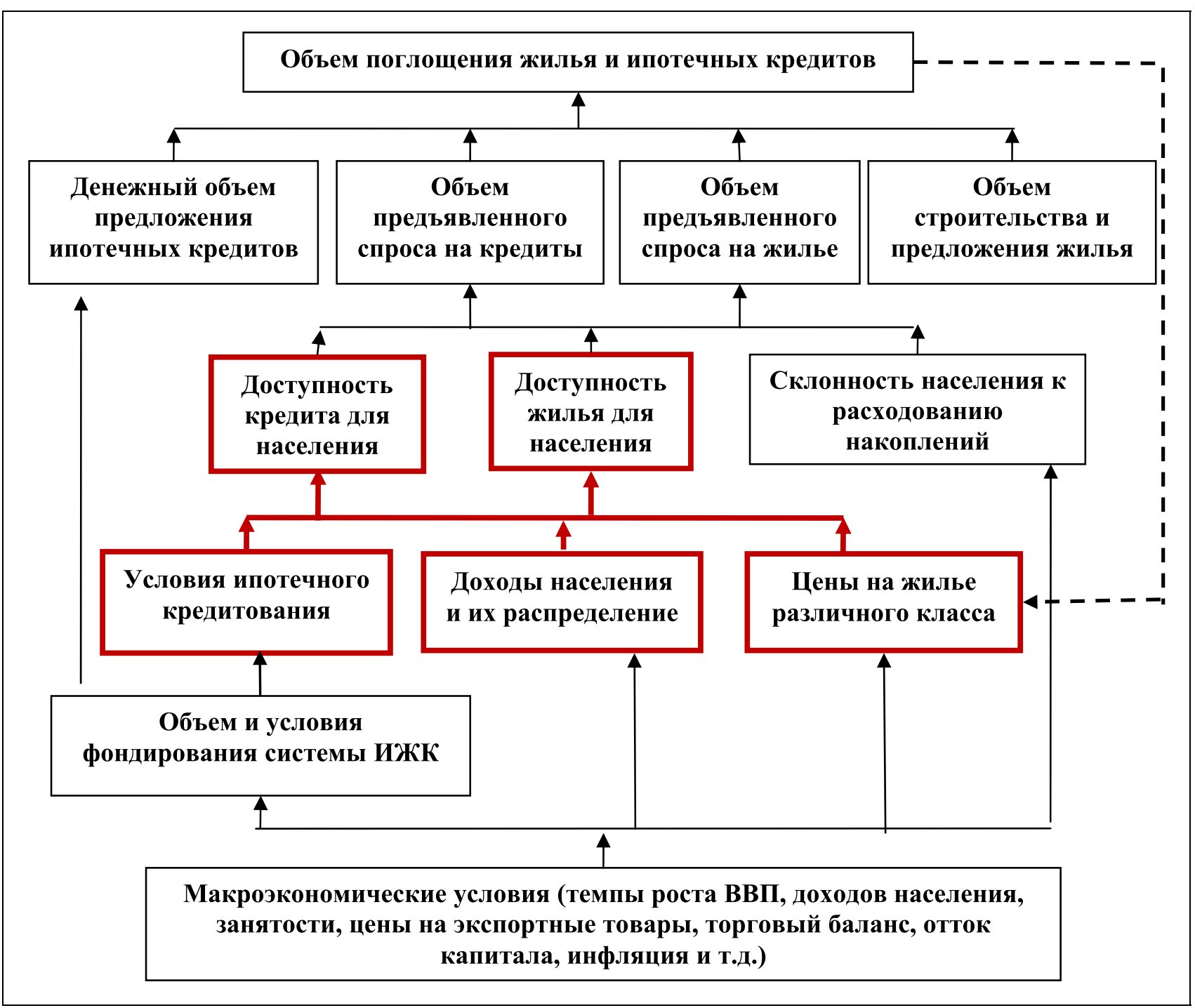

Рис. 2. Факторы, определяющчие объем ипотечного кредитования

Доступность жилья для населения жилья зависит от уровня доходов населения и цен на жилье, а доступность ипотеки - еще и от условий ипотечного кредитования (см. рис. 2).

Если начать с условий ипотечного кредитования, то они определяются в первую очередь уровнем инфляции, а также условиями фондирования банков. В настоящих макроэкономических условиях происходит некоторое ухудшение обоих этих показателей, что приводит к повышению ставок ипотечного кредитования.
Уровень доходов населения напрямую связан с макроэкономическими условиями. В последние два года рост его практически остановился, и даже наметилась опасность снижения.

Цены на жилую недвижимость зависят от макроэкономических условий, и в значительной степени - от уровня доходов населения (см. рис. 2). Кроме того, они связаны с объемом ипотеки прямыми и обратными связями. Рост цен снижает доступность жилья и ипотеки, в первую очередь для малодоходных слоев населения, и вынуждает эти слои уходить с рынка, при 




Рис. 3. Темпы роста банковских активов в России

этом объем поглощения жилья и кредитов снижается. Стабильные и тем более плавно снижающиеся цены повышают доступность жилья и ипотеки и способствуют повышению объемов ипотечного кредитования (прямые связи). Рост объемов ипотечного кредитования толкает цены вверх, снижение - способствует стабилизации цен (обратные связи - см. пунктир на рис. 2). Так, в период послекризисного восстановления рынка в 2011-2012 годах, когда цены на жилье росли, доля ипотечных сделок в РФ снизилась с 20,8\% до 18,4\%. В период стагнации в 2013-2014 годах, когда цены были стабильны, доля ипотечных сделок выросла до $23,2 \%$ (рис. 4 ).

Следующий фактор, влияющий на объем ипотеки (см. рис. 2) - склонность населения к расходованию сбережений - зависит от макроэкономических условий в стране. При снижении темпов роста доходов, повышенных инфляционных ожиданиях, резкой (и/или длительной) девальвации рубля население ограничи- вает свои расходы в части дорогостоящих покупок (в том числе жилья), что приводит к снижению спроса на жилье и ипотеку.

В краткосрочном периоде (февраль-апрель 2014 года), когда стагнация в экономике уже было общепризнанной, склонность населения к инвестициям в жилье на фоне политических и макроэкономических событий последнего времени даже выросла. В условиях санации Центробанком РФ банковской системы, повышенных темпов девальвации рубля население рассматривало недвижимость чуть ли не как единственный способ сохранения сбережений. Но постепенно эффект этих шоков сгладился, и сегодня население, извлекая вклады из банков, скорее помещает их в банковские ячейки, а спрос на недвижимость снижается.

Итак, факторы, влияющие на поглощение жилья и ипотеки, находятся в сложном взаимодействии. Разработанная методика оценки доступности жилья для населения позволяет получить количественную 


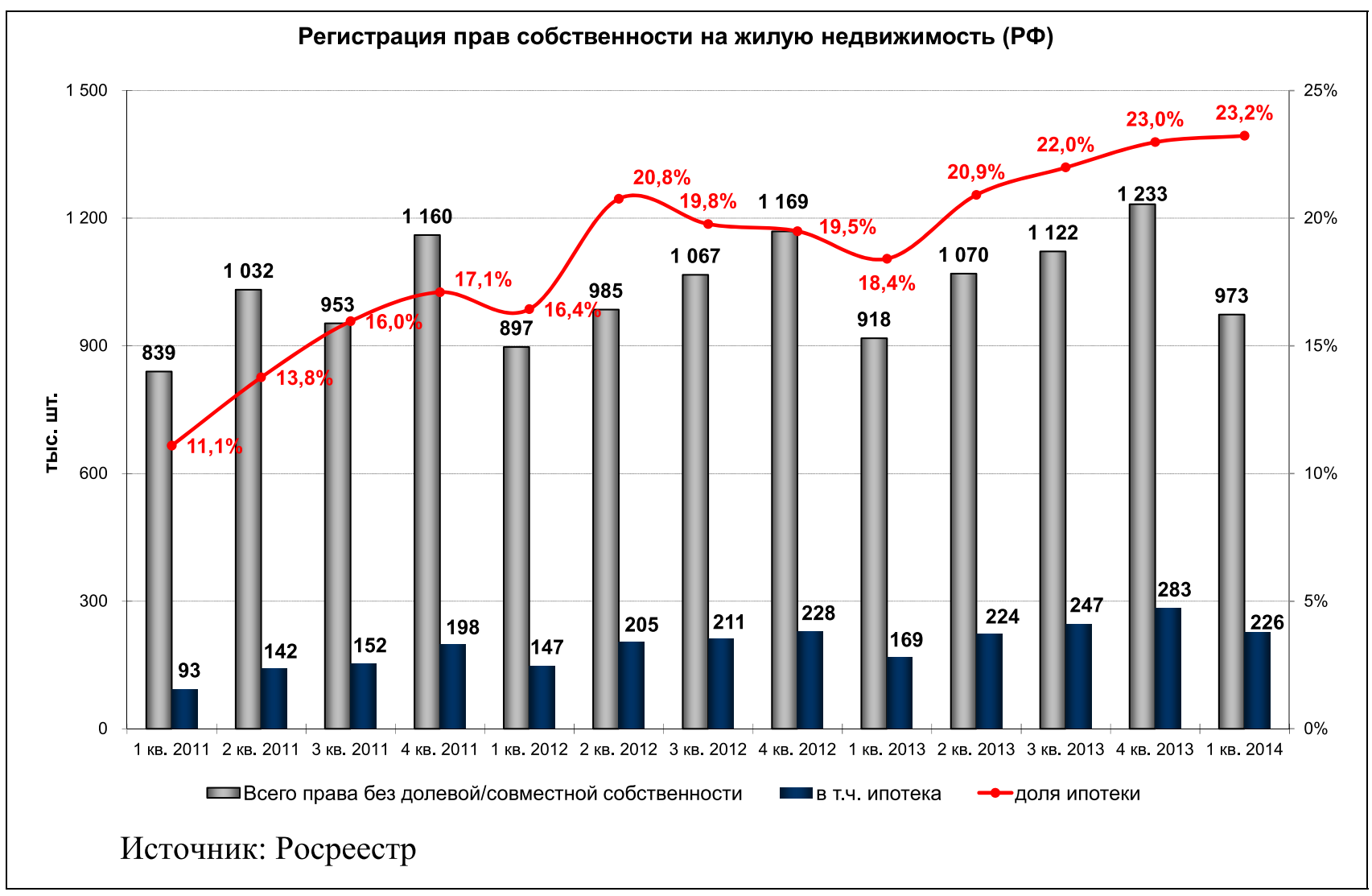

Рис. 4. Количество зарегистрированных прав на жилье и ипотечных сделок и доля ипотечных сделок в общем объеме регистрации прав

оценку влияния выделенных на рис. 2 факторов (цены на жилье и условия ипотечного кредитования, а именно ставка кредита, уровень доходов населения, а также уровень доходов населения) на доступность жилья (без ипотеки) и доступность кредита для населения.

В основу методики исследования положено представление о том, что доступное жилье - это жилье, которое семья может приобрести по рыночной стоимости, используя свои сбережения, накопленные из своих текущих доходов за разумный период времени (возможно, с учетом стоимости имеющейся квартиры) при необходимом уровне текущих расходов, а также используя при необходимости ипотечное кредитование и/или государственную поддержку, и при этом ее текущих доходов достаточно для обслуживания полученного кредита с момента приобретения жилья /5/.
Расчет в базовом варианте произведен на примере наиболее дорогого сегмента рынка - первичного рынка жилья Москвы в 2012 году. Исходные данные и результаты расчета приведены в работе $/ 2 /$.

Наличие адекватной математической модели процесса формирования доступности жилья/ипотеки для населения позволило провести расчетный эксперимент по оценке влияния стоимости жилья и уровня ипотечной ставки на долю населения, которой жилье/ипотека доступны. В качестве условий расчета были использованы:

- уровень цен на объекты 1-6 - базовый (2012 год) и изменение на 10, 20 и 30\% в ту и иную сторону;

- уровень ставки - базовый $(12,5 \%)$ и изменение на 1, 2 и 3 процентных пункта в ту и иную сторону;

- уровень доходов - базовый (2012 год и изменение на $10 \%$ в ту и другую сторону. 


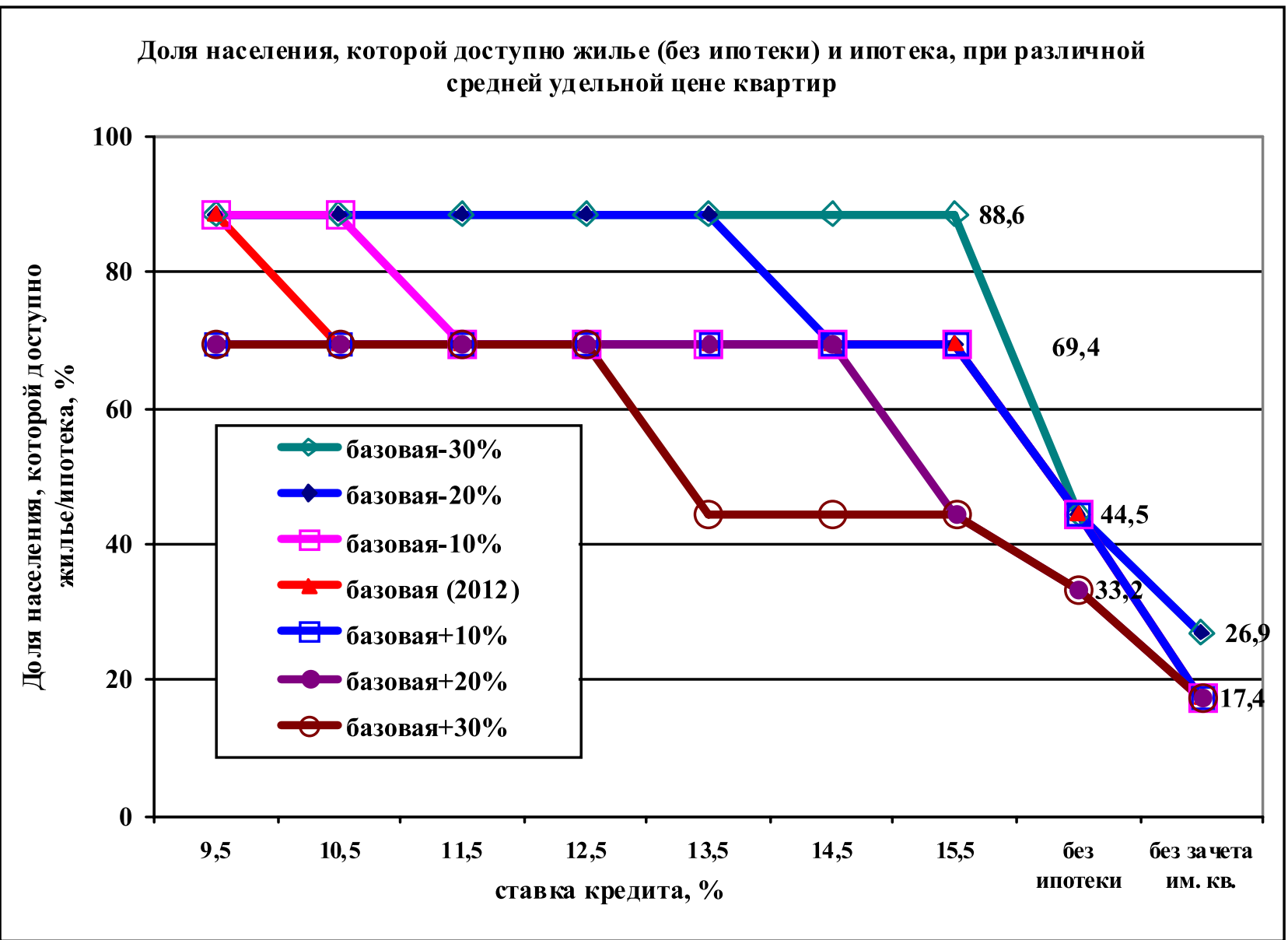

Рис. 5. Доля населения, которой доступно жилье (без ипотеки) и ипотека, при различной средней удельной цене квартир

Результаты расчета приведены на рис. 5-7.

Приведенные на рис. 5 данные показывают, что при уровне доходов москвичей, степени их расслоения, средних ценах на жилье различного класса, зафиксированных в 2012 году, жилье без ипотеки и без зачета имеющейся квартиры доступно 17,3\% москвичей, а с зачетом - 44,5\%. При этом структура доступности такова:

- объекты 5 и 6 доступны только группе 10 (1,0\% населения),

- объект 4 - также группам 8 и 9 (10,9\%),

- объект 3 - группе 7 (5,5\%),

- объект 2 - группам 5 и $6(15,8 \%)$,
- объект 1 - группе 4 (11,3\% населения),

- группам 1-3 жилье недоступно (55,5\% населения).

Группы населения 1 и 2 по своим доходам не могут получить кредит для покупки любого из объектов. Группы 3-5 могут получить кредит на покупку объекта 1 и 2, группы 6 и 7 - объектов 1, 2 и 3 , группа 8 - объектов $1,2,3,4$, группы 9 и 10 - всех объектов. Кредит на покупку объектов 1 и 2 может получить 69,4\% москвичей, 3 - 26,9\%, 4 - 11,9\%, 5 $-5,2 \%, 6-1,0 \%$. Доля населения, которой кредит доступен, составляет для объекта 1 и 2 - 69,4\%, 3 


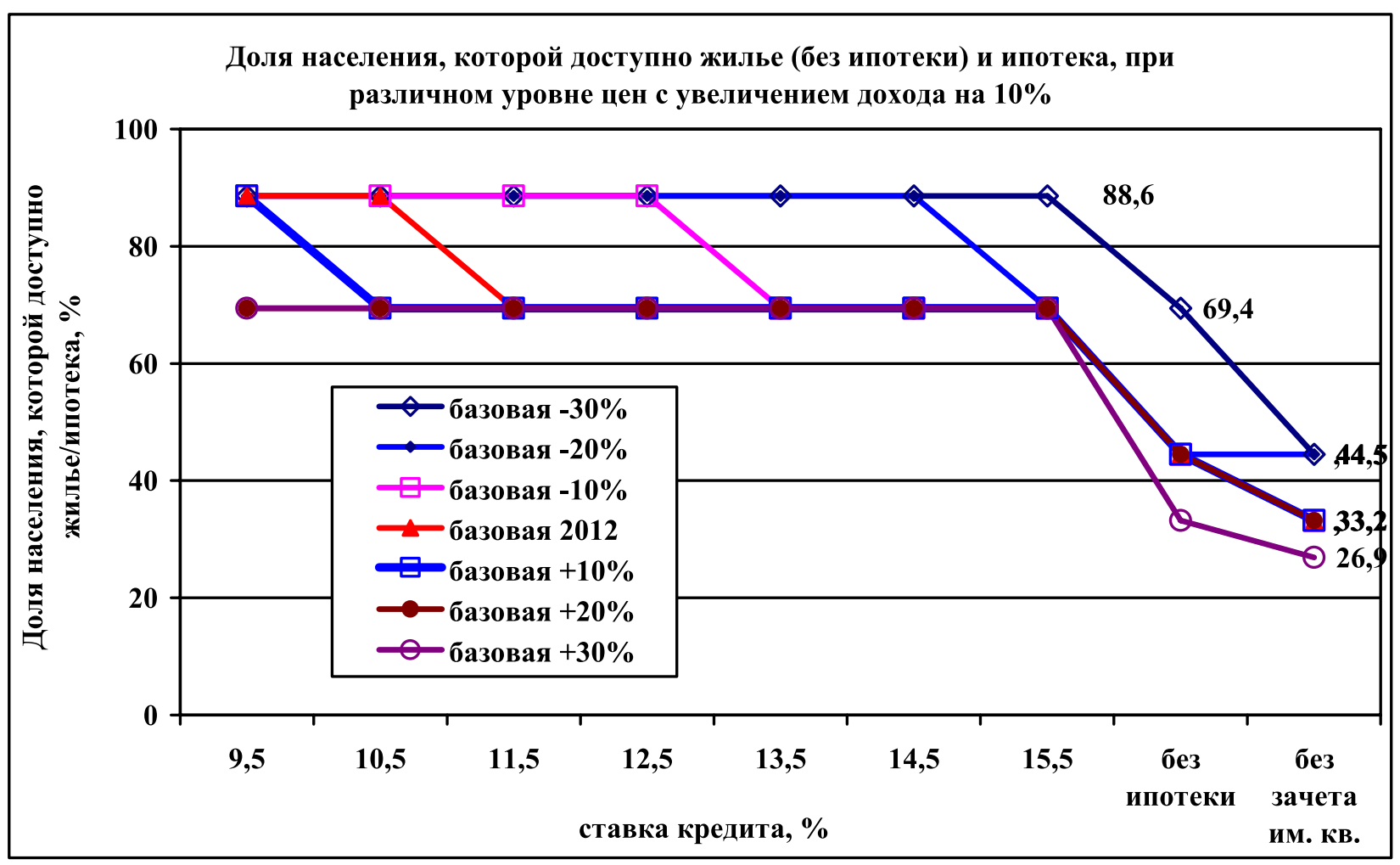

Рис. 6. Доля населения, которой доступно жилье (без ипотеки) и ипотека, при различном уровне иен с увеличением дохода на $10 \%$

$-44,5 \%, 4-33,3 \%, 5-11,9 \%, 6-5,2 \%$. Суммарная доля населения, которой ипотека доступна, составляет $69,4 \%$.

При изменении средней удельной цены квартир в широких пределах доля населения, которой жилье без ипотеки доступно, сохраняется на уровне 44,5\% (меняется лишь структура населения, которой жилье доступно, по группам доходности). Но при повышении средних цен на $30 \%$ эта величина снижается до $33,2 \%$. Без зачета имеющейся квартиры она находится в пределах 17,4-26,9\%.

При базовых значениях средней цены и изменении ставки кредита в широких пределах доля населения, которой доступен кредит, сохраняется на уровне $69,4 \%$, и только при снижении ставки до 9,5\% эта доля вырастает до $88,6 \%$.

При снижении средних цен на $10 \%$ этот рост происходит уже при ставке 10,5\%, на 20\% - при ставке $13,5 \%$, на $30 \%$ - при ставке $15,5 \%$.
При повышении средних цен на $10 \%$ рост доли населения, которой доступен кредит, при ставке 9,5\% уже не происходит, при повышении цен на 20\% и ставки до $15,5 \%$ эта доля снижается до 44,5\%, а при росте цен на $30 \%$ - снижается уже при ставке 13,5\%.

Таким образом, при доходах населения на уровне 2012 года и сложившихся стабильных ценах на жилье, близких к уровню 2012 года, изменение процентных ставок в пределах 11,5-15,5\% практически не влияет на долю населения, которой доступен кредит на покупку жилья, а повышение этой доли возможно лишь при снижении ставок до 9,5-10,5\%. Изменение цен начинает существенно влиять на доступность жилья и ипотеки при 20\%-м росте или снижении.

При увеличении уровня доходов на 10\% (рис. 6) доля населения, которой доступно жилье без ипотеки и без зачета имеющейся квартиры, находится в пределах 26,9-44,5\% в зависимости от уровня цен на жилье, т.е. вырастает относительно варианта доходов 


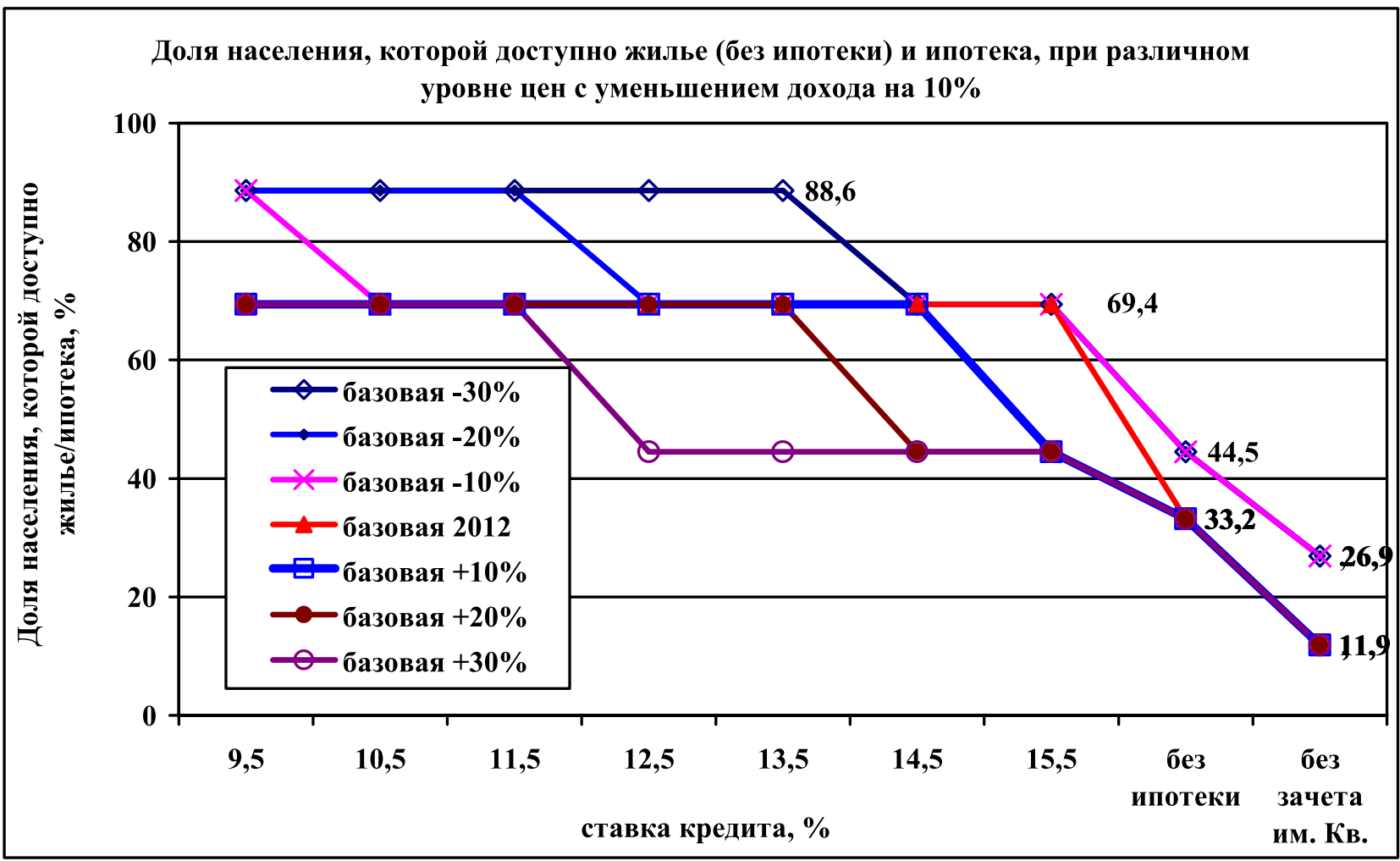

Рис. 7. Доля населения, которой доступно жилье (без ипотеки) и ипотека, при различном уровне цен с уменьшением дохода на 10\%

2012 года в 1,55-1,65 раза. С учетом имеющейся квартиры - 33,2-69,4\%, рост в $1,0-1,56$ раза в зависимости от уровня цен.

При изменении ипотечной ставки в пределах 9,515,5\% доля населения, которой доступна ипотека, составляет $69,4-88,6 \%$, рост в $1,56-1,00$ раз. При этом повышение показателя до 88,6\% происходит уже при базовых ценах и ставке $10,5 \%$, а при пониженных на $10 \%$ ценах - при ставке $12,5 \%$, на $20 \%$ - при ставке $14,5 \%$, на $30 \%$ - при ставке $15,5 \%$.

При понижении доходов населения на 10\% (рис. 7) доля населения, которой доступно жилье без ипотеки и без зачета имеющейся квартиры, понижается до 11,9-26,9\% (снижение относительно базового варианта доходов в 1,46-1,00 раза). При базовых ценах и ставках дохода во всем диапазоне максимальное значение показателя составляет лишь 69,4\%. Повышение до $88,6 \%$ происходит только при снижении цен на 10\% и ставки до 9,5\%, либо цены на 20\% и ставки до $11,5 \%$, либо цены на $30 \%$ и ставки до 13,5\%.

Таким образом, в пределах возможного реального изменения значений исследованных факторов значимость факторов с точки зрения их влияния на доступность жилья и ипотеки ранжируется в следующем порядке: уровень доходов; уровень цен на жилую недвижимость; ставка кредита.

Задачей дальнейших исследований является оценка влияния доступности жилья, а также остальных показанных на рис. 2 факторов на объем поглощения жилья и ипотеки, с учетом всего комплекса прямых и обратных связей. Для этого в настоящее время осуществляется встраивание методики оценки доступности жилья для населения в модель развития локального рынка жилой недвижимости /2/ в качестве модуля и совершенствование алгоритма модели в части учета структуры спроса на жилье и ипотеку. 


\section{Библиография}

1. Стерник Г.М. Ипотечные качели на рынке жилья Москвы. - Журнал «Имущественные отношения в РФ» №5 (80), 2008.-С. 7-16.

2. Стерник Г.М., Апальков А.А. Развитие методики оценки доступности жилья для населения // «Имущественные отношения в Российской Федерации».-2014.-№4. - С. 59-71.

3. Стерник Г.М., Апальков А.А. Новая методика оценки доступности жилья для населения // Журнал «Урбанистика и рынок недвижимости». - 2014 (в печати).

4. Лепетиков Д.В. Основные тенденции российского банковского сектора // Доклад на Аналитической конференции МАР 29.08.2014.

5. Стерник Г.М. Доступное жилье - что это такое? - В сб. «Правовые и организационно-экономические основы формирования рынка доступного жилья в Москве». - РЭА им. Г.В.Плеханова (под ред. Стерника Г.М.).-М.: 2006.-С. 3-17.

6. Устойчивое развитие современных крупных городов: теория, опыт, проблемы. Материалы международной научно-практической конференции. Минск, Минский НИИ социально-экономических и политических проблем, 2002. - 372 с.

7. Кияненко К.В. Введение в проблематику современного рыночного жилища: Учебное пособие для архитектурных и строительных специальностей вузов. Вологда: ВоГТУ. 2002. 172 с.

8. Сидоренко А. Жилищная фильтрация и движение жилищного фонда // Архитектура и строительство. 2005. №2.

9. Жилищная экономика. Пер. с англ. - М.; Дело,1996. - 224 с.

10. Итоги переписи населения 2010 года. Том 9. Жилищные условия домашних хозяйств. Федеральная служба государственной статистики. М.: 2012.

11. Сводом правил «Градостроительство, планировка и застройка территорий городских и сельских поселений» (СП 42.13330.2011), введен в действие 20.05.2011 г.

12. Итоги переписи населения 2002 года. Том 14. Жилищные условия домашних хозяйств. Федеральная служба государственной статистики. М.: 2004.

13. Ежегодный бюллетень жилищной и строительной статистики для Европы и Северной Америки: 1980,1990,1991,1993. Том XXXVII 1993. - Нью-Йорк; Женева: ООН, 1995. - 209 с.

14. Стратегия-2020: Новая модель роста - новая социальная политика. Итоговый доклад о результатах экспертной работы по актуальным проблемам социально-экономической стратегии России на период до 2020 года. Книга 2. Глава 14. Государственная жилищная политика; под научн. ред. В.А. Мау, Я.И. Кузьминкова.—М: Издательский дом «Дело» РАНХиГС, 2013. -408 с.

15. Сидоренко А. Д. Жилищное строительство в Республике Беларусь в 1996-2000 годы (Социально-экономические результаты и тенденции) - Минск: Ин-т социал.-полит. исследований, 2001. - 144c.

16. Догодайло В., Сидоренко А. Интегрированная оценка условий заселения домашних хозяйств и жилых помещений // Экономическая политика. 2013. №6.

17. А. В. Широков. Конституционное право на жилье и «социальное жилье» в России. // Право и политика.2008.-№3.

18. О. Е. Жульева. Структура договорных отношений в сфере управления многоквартирным жилым домом. // Право и политика.-2008.-№2. 
19. Д.В. Карпухин. Конституционное право на жилье и выселение из жилого помещения без предоставления другого жилища: проблемы соотношения неотчуждаемости права и возможности его практического лишения.. // Право и политика.-2007.-№1.

20. Д. Пашов. Государственный жилищный ипотечный банк в Национальном проекте «Доступное и комфортное жилье - гражданам России».. // Право и политика.-2006.-№10.

21. С.И. Суслова. О требовании гуманности в жилищном праве. // Право и политика.-2013.-№2.-C. 202-207. DOI: 10.7256/1811-9018.2013.02.6.

22. М. А. Калюжная. Коррупционные правонарушения в сфере жилищного обеспечения военнослужащих - показатель неэффективности механизма правового регулирования.. // Национальная безопасность / nota bene.-2010.-№9.

23. Игонин Д.И.. Определение стратегических приоритетов в государственной миграционной политике России как превентивная мера социальной дезадаптации.. // Тренды и управление.-2013.-№4.-C. 41-57. DOI: 10.7256/2307-9118.2013.4.4880.

24. Федякин И.В.. Мегаполисы как субъекты политики: история и современное состояние. // Международные отношения.-2014.-№1.-C. 88-93. DOI: 10.7256/2305-560X.2014.1.10165.

\section{References (transliterated)}

1. Sternik G.M. Ipotechnye kacheli na rynke zhil’ya Moskvy. - Zhurnal «Imushchestvennye otnosheniya v RF» №5 (80), 2008.-S. 7-16.

2. Sternik G.M., Apal'kov A.A. Razvitie metodiki otsenki dostupnosti zhil'ya dlya naseleniya // «Imushchestvennye otnosheniya v Rossiiskoi Federatsii».-2014.-№4. - S. 59-71.

3. Sternik G.M., Apal'kov A.A. Novaya metodika otsenki dostupnosti zhil'ya dlya naseleniya // Zhurnal «Urbanistika i rynok nedvizhimosti». - 2014 (v pechati).

4. Lepetikov D.V. Osnovnye tendentsii rossiiskogo bankovskogo sektora // Doklad na Analiticheskoi konferentsii MAR 29.08.2014.

5. Sternik G.M. Dostupnoe zhil'e - chto eto takoe? - V sb. «Pravovye i organizatsionno-ekonomicheskie osnovy formirovaniya rynka dostupnogo zhil'ya v Moskve». - REA im. G.V.Plekhanova (pod red. Sternika G.M.).-M.: 2006.-S. 3-17.

6. Ustoichivoe razvitie sovremennykh krupnykh gorodov: teoriya, opyt, problemy. Materialy mezhdunarodnoi nauchno-prakticheskoi konferentsii. Minsk, Minskii NII sotsial'no-ekonomicheskikh i politicheskikh problem, 2002. $-372 \mathrm{~s}$.

7. Kiyanenko K.V. Vvedenie v problematiku sovremennogo rynochnogo zhilishcha: Uchebnoe posobie dlya arkhitekturnykh i stroitel'nykh spetsial'nostei vuzov. Vologda: VoGTU. 2002. $172 \mathrm{s.}$

8. Sidorenko A. Zhilishchnaya fil’tratsiya i dvizhenie zhilishchnogo fonda // Arkhitektura i stroitel’stvo. 2005.

9. Zhilishchnaya ekonomika. Per. s angl. - M.; Delo,1996. - 224 s.

10. Itogi perepisi naseleniya 2010 goda. Tom 9. Zhilishchnye usloviya domashnikh khozyaistv. Federal'naya sluzhba gosudarstvennoi statistiki. M.: 2012.

11. Svodom pravil «Gradostroitel'stvo, planirovka i zastroika territorii gorodskikh i sel'skikh poselenii» (SP 42.13330.2011), vveden v deistvie 20.05.2011 g.

12. Itogi perepisi naseleniya 2002 goda. Tom 14. Zhilishchnye usloviya domashnikh khozyaistv. Federal'naya sluzhba gosudarstvennoi statistiki. M.: 2004. 
13. Ezhegodnyi byulleten' zhilishchnoi i stroitel'noi statistiki dlya Evropy i Severnoi Ameriki: 1980,1990,1991,1993. Tom KhKhKhVII 1993. - N'yu-Iork; Zheneva: OON, 1995. - 209 s.

14. Strategiya-2020: Novaya model' rosta - novaya sotsial'naya politika. Itogovyi doklad o rezul'tatakh ekspertnoi raboty po aktual'nym problemam sotsial'no-ekonomicheskoi strategii Rossii na period do 2020 goda. Kniga 2. Glava 14. Gosudarstvennaya zhilishchnaya politika; pod nauchn. red. V.A. Mau, Ya.I. Kuz'minkova.—M: Izdatel'skii dom «Delo» RANKhiGS, 2013. $-408 \mathrm{~s}$.

15. Sidorenko A. D. Zhilishchnoe stroitel'stvo v Respublike Belarus' v 1996-2000 gody (Sotsial'no-ekonomicheskie rezul'taty i tendentsii) - Minsk: In-t sotsial.-polit. issledovanii, 2001. - 144s.

16. Dogodailo V., Sidorenko A. Integrirovannaya otsenka uslovii zaseleniya domashnikh khozyaistv i zhilykh pomeshchenii // Ekonomicheskaya politika. 2013. №6.

17. A. V. Shirokov. Konstitutsionnoe pravo na zhil’e i «sotsial’noe zhil'e» v Rossii. // Pravo i politika.-2008.-№3.

18. O. E. Zhul'eva. Struktura dogovornykh otnoshenii v sfere upravleniya mnogokvartirnym zhilym domom. // Pravo i politika.-2008.-№2.

19. D.V. Karpukhin. Konstitutsionnoe pravo na zhil'e i vyselenie iz zhilogo pomeshcheniya bez predostavleniya drugogo zhilishcha: problemy sootnosheniya neotchuzhdaemosti prava i vozmozhnosti ego prakticheskogo lisheniya.. // Pravo i politika.-2007.-№1.

20. D. Pashov. Gosudarstvennyi zhilishchnyi ipotechnyi bank v Natsional'nom proekte «Dostupnoe i komfortnoe zhil'e - grazhdanam Rossii».. // Pravo i politika.-2006.-№10.

21. S.I. Suslova. O trebovanii gumannosti v zhilishchnom prave. // Pravo i politika.-2013.-№2.-C. 202-207. DOI: 10.7256/1811-9018.2013.02.6.

22. M. A. Kalyuzhnaya. Korruptsionnye pravonarusheniya v sfere zhilishchnogo obespecheniya voennosluzhashchikh — pokazatel' neeffektivnosti mekhanizma pravovogo regulirovaniya.. // Natsional'naya bezopasnost' / nota bene.2010.-№9.

23. Igonin D.I.. Opredelenie strategicheskikh prioritetov v gosudarstvennoi migratsionnoi politike Rossii kak preventivnaya mera sotsial'noi dezadaptatsii.. // Trendy i upravlenie.-2013.-№4.-C. 41-57. DOI: 10.7256/23079118.2013.4.4880.

24. Fedyakin I.V.. Megapolisy kak sub"ekty politiki: istoriya i sovremennoe sostoyanie.// Mezhdunarodnye otnosheniya.2014.-№1.-C. 88-93. DOI: 10.7256/2305-560X.2014.1.10165. 